\title{
PRAKTIK PENGAWASAN PENGELOLAAN KEUANGAN SEKOLAH
}

\author{
Sri Rahayu ${ }^{1)}$, Mukhzarudfa $^{2)}$, Yuliusman $^{3)}$, Yuliana $^{4)}$ \\ Dosen Jurusan Akuntansi FEB Universitas Jambi \\ srijambi@gmail.com; sri_rahayu@unja.ac.id
}

\begin{abstract}
The purpose of this research to uncover the practice of supervision on school financial management. The data used in the form of primary to be collected through the questionnaire and in-depth interviews. Respondents and informants of this study were school principals and supervisors. Quantitative and qualitative research methods were used in this study. The results of the research show that supervision at the planning and implementation stage is very good, as evidenced by the involvement of stakeholders in the preparation of school plans, although with different patterns. Supervision at the reporting and accountability stage are still at a good position. The role of supervisor is very needed in supervising school financial management. Supervisory competence regarding financial management must be improved through training, socialization and technical guidance.
\end{abstract}

Keywords : School, supervision, efficiency and effective

\begin{abstract}
ABSTRAK
Tujuan penelitian ini untuk mengungkap praktik pengawasan pengelolaan keuangan sekolah. Data yang digunakan berupa data primer yang akan dikumpulkan melalui kuesioner dan wawancara mendalam. Responden dan informan penelitian ini adalah kepala sekolah dan pengawas sekolah. Metode penelitian kuantitatif dan kualitatif digunakan pada penelitian ini. Hasil riset menunjukkan pengawasan pada tahap perencanaan dan pelaksanaan sangat baik, terbukti dengan keterlibatan stakeholders dalam penyusunan rencana sekolah, walaupun dengan pola yang berbeda-beda. Pengawasan pada tahap pelaporan dan pertanggungjawaban masih berada pada posisi baik. Peran pengawas sangat dibutuhkan dalam pengawasan pengelolaan keuangan sekolah. Kompetensi pengawas tentang pengelolaan keuangan harus ditingkatkan melalui pelatihan, sosialisasi dan bimbingan teknis.
\end{abstract}

Kata Kunci : Sekolah, Pengawasan, efisiensi dan efektif. 


\section{PENDAhuluan}

\subsection{Latar Belakang}

Sekolah harus mengelola keuangan dengan baik karena sangat penting untuk mencapai pendidikan yang berkualitas. Kondisi sektor pendidikan Indonesia saat ini terus mengalami kemerosotan. Indikator yang menunjukkan pendidikan Indonesia masuk ke tahap fase darurat dapat dilihat antara lain dari banyaknya bangunan sekolah yang rusak, peningkatan jumlah siswa putus sekolah, angka buta aksara yang tinggi dan human development index (HDI) rendah (Irawan, Eriyanto, Djani, dan Sunaryanto, 2004, hlm. 7).

Pengukuran perbandingan dari harapan hidup, melek huruf, pendidikan dan standar hidup untuk semua negara seluruh dunia dikenal dengan istilah Indek Pembangunan Manusia (IPM) yang juga sering disebut HDI. Salah satu klasifikasi yang digunakan untuk menentukan suatu negara termasuk kelompok negara maju, berkembang atau terbelakang menggunakan HDI. Selain itu juga sering digunakan sebagai ukuran dampak kebijakan ekonomi terhadap kualitas hidup.

Pembangunan manusia di Indonesia terus mengalami kemajuan (BPS, 2018). Perkembangan HDI Indonesia berdasarkan hasil survei dari UNDP disajikan pada tabel 1.1.

Tabel 1. Perkembangan HDI Value Indonesia Beberapa Tahun Terakhir

\begin{tabular}{|c|c|}
\hline Tahun & Human Development Index Value \\
\hline 1990 & 0,528 \\
\hline 1995 & 0,564 \\
\hline 2000 & 0,606 \\
\hline 2005 & 0,632 \\
\hline 2010 & 0,661 \\
\hline 2015 & 0,686 \\
\hline 2016 & 0,691 \\
\hline 2017 & 0,694 \\
\hline
\end{tabular}

Sumber: UNDP, 2018.

Berdasarkan tabel 1 dapat dilihat memang terjadi kenaikan HDI untuk beberapa tahun terakhir, namun perkembangannya tergolong lambat. Apabila dibandingkan dengan perkembangan HDI Cina dan Thailand, terlihat trend yang sangat cenderung rendah, yang ditunjukkan pada Gambar 1.

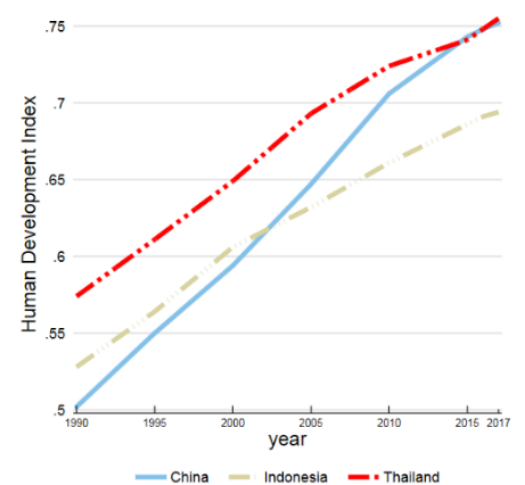

Gambar 1. Perbandingan Perkembangan HDI Sumber: UNDP, 2018
Indonesia jauh tertinggal dari negara-negara tetangga dari sisi HDI. Berdasarkan laporan rata-rata HDI tahun 1980-2013 yang diterbitkan oleh United Nations Development Programme (UNDP) pada 15 November 2013, Indonesia menduduki posisi ke-108 dari 187 negara di dunia. HDI negara tetangga lain lebih baik dibandingkan Indonesia, seperti Singapura pada peringkat ke-9, Brunei Darussalam pada peringkat ke-30, Malaysia pada peringkat ke-62 dan Thailand pada peringkat ke-89 (UNDP, 2013). Tahun 2017, Indonesia masih berada di posisi 116 dari 189 negara (UNDP, 2018).

Walaupun peringkat yang ditunjukkan oleh HDI bukan satu-satunya sebagai pengukur keberhasilan pendidikan di suatu negara, tetapi setidak-tidaknya bisa memberikan gambaran keberhasilan pendidikan, kesehatan dan ekonomi suatu negara. Pengetahuan yang mengukur angka tingkat baca tulis pada orang dewasa (bobotnya dua per tiga) dan kombinasi pendidikan dasar, menengah, atas gross enrollment ratio (bobot satu per tiga) menjadi indikator untuk mengukur HDI di bidang pendidikan. Banyak unsurunsur lain yang juga harus diperhatikan untuk melihat keberhasilan pendidikan seperti kemajuan teknologi suatu negara, tingkat inovasi yang dikembangkan, pemerataan akses pendidikan, moralitas generasi muda dan lain sebagainya.

Perhatian pemerintah terhadap pendidikan dibuktikan dengan alokasi anggaran untuk mendukung operasional sekolah dalam bentuk dana bantuan operasional sekolah (BOS). Tambah,,,, dari rahayu (2015); 2015. Sebelum berlakunya UU No. 20 Tahun 2003, berlaku UU No. 2 tahun 1989 tentang Sistem Pendidikan Nasional. Pendanaan pendidikan tidak diatur secara khusus dalam UU lama tersebut. UU No. 20 tahun 2003 mengatur pendanaan pendidikan secara khusus dalam Bab XIII, yang substansinya antara lain:

1. Pendanaan pendidikan menjadi tanggung jawab bersama antara Pemerintah, Pemerintah Daerah, dan Masyarakat.

2. Sumber pendanaan pendidikan ditentukan berdasarkan prinsip keadilan, kecukupan, dan keberlanjutan.

3. Pengelolaan dana pendidikan berdasarkan prinsip keadilan, efisiensi, transparansi, dan akuntabilitas publik.

4. Alokasi dana pendidikan selain dana gaji pendidik dan biaya pendidikan kedinasan sebesar minimal $20 \%$ dari APBN untuk sektor pendidikan dan minimal 20\% dari APBD. Alokasi dana dari pemerintah dan pemerintah daerah ke satuan pendidikan dalam bentuk hibah.

Sekolah harus menggunakan dana yang diterima secara efisien dan efektif untuk peningkatan pelayanan dan kualitas pendidikan (Bastian, 2007, hlm. 52). Semangat akuntabilitas dan transparansi harus mendasari pengelolaan dana baik dari pemerintah maupun dari masyarakat. Dana yang dikelola secara 
transparan menjadikan masyarakat dapat mengetahui pengunaan dan alokasi belanja yang bersumber dari dana sekolah. Setiap kepala sekolah harus menyampaikan pertanggungjawaban serta hasil yang diperoleh setiap periode terkait penerimaan dan pengeluaran keuangan sekolah kepada orang tua siswa, komite, masyarakat dan pemerintah. Dengan demikian, sekolah harus mampu menyelenggarakan pengelolaan keuangan secara transparan. Akuntabilitas publik khususnya bagi pengguna jasa pendidikan akan terjamin (Bastian, 2007, hlm. 44).

Alokasi dana BOS tidak dapat dikatakan sedikit. Sekolah menerima dana BOS sesuai dengan jumlah siswa sebagai peserta didik. Sekolah menerima Rp. 1.000.000,- rupiah untuk setiap siswa. Alokasi jumlah dana BOS yang disalurkan pemerintah dapat dilihat pada tabel 2.

Tabel 2. Jumlah Alokasi Dana BOS

Per Triwulan Tahun 2018 (Jutaan Rupiah)

\begin{tabular}{|c|r|r|r|}
\hline $\begin{array}{c}\text { Alokasi } \\
\text { Tahun } \\
2018\end{array}$ & $\begin{array}{c}\text { Alokasi Dana } \\
\text { BOS-Nasional }\end{array}$ & $\begin{array}{c}\text { Alokasi } \\
\text { Dana BOS- } \\
\text { Provinsi } \\
\text { Jambi }\end{array}$ & $\begin{array}{c}\text { Alokasi Dana } \\
\text { BOS-Prov } \\
\text { Jambi Tingkat } \\
\text { SD }\end{array}$ \\
\hline Triwulan1 & 9.342 .283 & 127.515. & 62.853 \\
\hline Triwulan2 & 17.719 .775 & 253.009 & 125.660 \\
\hline Triwulan3 & 8.381 .775 & 120.165 & 56.751 \\
\hline Triwulan4 & 8.727 .675 & 120.762 & 68.371 \\
\hline Jumlah & 44.171 .508 & 621.452 & 194.032 \\
\hline
\end{tabular}

\section{Sumber: Kemdikbud, 2018}

Jumlah dana yang dialokasikan pada tahun 2018, sebanyak Rp.44,1 Trilyun secara nasional untuk seluruh sekolah bukan jumlah yang sedikit. Sekolah di Provinsi Jambi mendapatkan alokasi anggaran 1,41\% dari total dana tersebut.

Selain dana BOS, sebagian sekolah juga menerima dana bantuan pemerintah (Bantah). Perbedaan antara dana BOS dan dana Bantah, dana BOS digunakan untuk membiayai operasional sekolah, sedangkan dana Bantah khusus dialokasikan untuk sarana dan prasarana sekolah. Seperti halnya dana BOS yang diberikan otonomi penuh ke sekolah untuk mengelolanya, diterima secara penuh tanpa potongan. Pola swakelola juga diterapkan dalam pengelolaan dana Bantah yang diterima sekolah. Jumlah dana Bantah yang diterima oleh Kabupaten/Kota di Provinsi Jambi juga signifikan, terlihat pada tabel 3 .

\begin{tabular}{|c|c|c|c|}
\hline \multicolumn{4}{|c|}{ Tabel 3.} \\
\hline \multicolumn{4}{|c|}{ Jumlah Penerimaan Bantuan Pemerintah Bidang Pendidikan } \\
\hline \multicolumn{4}{|c|}{ Kabupaten dan Kota serta Provinsi Jambi } \\
\hline \multicolumn{4}{|c|}{ Tahun $2017-2018$} \\
\hline \multicolumn{4}{|c|}{ (Dalam Rupiah) } \\
\hline No & Daerah & 2017 & 2018 \\
\hline 1 & Prov. Jambi & 132.098 .213 .139 & 84.694 .729 .643 \\
\hline 2 & Kab. Batanghari & 8.096 .209 .662 & 6.947 .259 .000 \\
\hline 3 & Kab. Bungo & 7.205 .364 .000 & 11.660 .898 .000 \\
\hline 4 & Kab. Sarolangun & 14.577.488.355 & 10.068 .258 .800 \\
\hline 5 & Kab. Tanjung Jabung Barat & 15.417 .732 .000 & 9.417 .995 .000 \\
\hline 6 & Kab. Kerinci & 16.632 .735 .004 & 7.474 .893 .400 \\
\hline 7 & Kab. Tebo & 18.606.306.516 & 8.211 .768 .000 \\
\hline 8 & Kab. Muaro Jambi & 9.305 .938 .102 & 9.984 .743 .120 \\
\hline 9 & Kab. Tanjung Jabung Timur & 12.579 .472 .000 & 7.168 .056 .123 \\
\hline 10 & Kab. Merangin & 19.997.257.000 & 8.758 .499 .300 \\
\hline 11 & Kota Jambi & 25.178 .939 .000 & 16.973.246.700 \\
\hline 12 & Kota Sungai Penuh & 5.628 .423 .500 & 3.893 .918 .200 \\
\hline
\end{tabular}

Sumber: Kemdikbud.go.id, 2018

Kota Jambi menerima dana Bantah paling tinggi dibandingkan Kabupaten/Kota di Provinsi Jambi.

Setiap sekolah harus melakukan penatausahaan keuangan secara baik dan tertib atas dana yang diterima mulai dari penyusunan Rencana Kerja dan Anggaran Sekolah (RKAS) sampai dengan penyusunan laporan pertanggungjawaban penggunaan dana. Pengelolaan dana sekolah menggunakan School Based Management atau manajemen berbasis sekolah (MBS) artinya sekolah menerima dana secara utuh dan sekolah mengelola secara mandiri dengan mengikutsertakan dewan guru dan komite sekolah. Prinsip profesional, transparan dan akuntabel harus dipatuhi sekolah dalam mengelola dana yang diterimanya (Kemdikbud, 2012). Mutu pendidikan diharapkan dapat dicapai melalui pemberdayaan sekolah dengan otonomi, fleksibilitas yang lebih besar dalam mengelola sumber daya sekolah dan mendorong partisipasi warga sekolah dan masyarakat.

Penerapan MBS menuntut pengawasan dari berbagai pihak untuk menjamin pengelolaan keuangan sekolah berjalan sesuai aturan. Penelitian ini akan mengeksplorasi praktik pengawasan pengelolaan keuangan sekolah dasar. Penelitian dengan objek sekolah selama ini lebih banyak melihat dari sisi aspek akademis, aspek pengelolaan keuangan sekolah belum banyak digali.

Sekolah merupakan lembaga pendidikan yang menjadi penentu bagi kualitas penyelenggaran pendidikan yang akan meningkatkan mutu bangsa ke depan. Sekolah yang dipilih dalam penelitian ini adalah sekolah dasar, yang menjadi tonggak penentu pembentukan karakter dan kemampuan dasar anak bangsa. Kemandirian pengelolaan keuangan yang diberikan pemerintah kepada sekolah dapat berdampak positif maupun negatif bagi sekolah itu sendiri. Sekolah yang mampu mengelola dananya dengan baik, akan lebih leluasa menggunakan dana tersebut untuk peningkatan kualitas pendidikan anak didik. Sebaliknya, sekolah yang belum mampu atau lalai dalam mengelola dana yang dimilikinya juga akan berdampak terhadap penggunaan dana yang kurang 
tepat. Oleh karena itu, pengawasan pengelolaan keuangan sekolah sangat penting dilakukan.

Penelitian ini menggunakan pendekatan kualitatif untuk mampu menggali keadaan riil realitas pengawasan di lapangan. Fokus penelitian ini adalah Praktik pengawasan pengelolaan keuangan sekolah. Penelitian ini bertujuan untuk mengungkap dan menganalisis fenomena praktik pengawasan pengelolaan keuangan sekolah.

\section{TINJAUAN PUSTAKA}

\subsection{MBS sebagai dasar pengelolaan keuangan sekolah}

Pendidikan merupakan salah satu bidang kewenangan yang diberikan kepada daerah kabupaten dan kota sejak diterbitkannya UU No. 22 Tahun 1999 mengamanahkan bidang pendidikan dibawah kewenangan daerah Kabupaten dan Kota. Pemerintah daerah diberikan kekuasaan untuk menetapkan berbagai agenda pembangunan pendidikan dasar dan menegah di daerah dan tanggung jawab serta wewenang untuk perencanaan, manajemen, keuangan dan kegiatan lain yang terkait dengan kegiatan sekolah (Rifa'i, 2011). Penerapan desentralisasi ke dalam manajemen pendidikan menghadirkan sekolah sebagai suatu lembaga yang memiliki otoritas dan kewenangan yang lebih luas (Fattah, 2012). Perubahan otonomi pengelolaan pendidikan diubah dengan dikeluarkannya UU No. 23 Tahun 2014, Pengelolaan pendidikan dasar (SD dan SMP) diberikan kepada Kabupaten/Kota dan pengelolaan pendidikan tingkat SMA diserahkan kepada Provinsi.

Otonomi pendidikan selanjutnya diikuti dengan otonomi sekolah. Pengelolaan satuan pendidikan yang berdasarkan prinsip MBS yang telah ditetapkan oleh Pemerintah dalam UU No. 20 Tahun 2003 tentang Sistem Pendidikan Nasional merupakan bukti pemberlakuan otonomi sekolah. Ditinjau dari bahasa, MBS berasal dari tiga suku kata yaitu manajemen, berbasis dan sekolah. Manajemen adalah proses menggunakan sumber daya secara efektif untuk mencapai tujuan. Basis sebagai kata dasar basis adalah dasar atau asas. Sekolah merupakan lembaga untuk belajar dan mengajar serta tempat untuk menerima dan memberikan pelajaran. MBS dapat diartikan sebagai penggunaan sumber daya yang berasaskan pada sekolah dalam proses pembelajaran (Minarti, 2011). Secara sempit, MBS mengarah pada perubahan tanggung jawab pemerintah kepada sekolah meliputi pengelolaan anggaran, personel dan kurikulum (Zazin, 2011).

Pelaksanaan MBS berdasarkan pada prinsip utama yang menjadi platform manajemen sekolah. Prinsip utama MBS yaitu (1) fokus pada mutu; (2) bottom-up planning and decision making; (3) manajemen yang transparan; (4) pemberdayaan masyarakat; dan (5) peningkatan mutu yang berkelanjutan (Minarti, 2011). Penerapan prinsip utama ini akan menjadikan sekolah mampu mencapai tujuan MBS secara umum. Bastian (2007, p. 187) menyatakan bahwa penerapan MBS diharapkan dapat memperkuat relevansi lembaga pendidikan, memperkuat partisipasi masyarakat, memperkuat kreativitas dan kemandirian individu dan lembaga serta memperkuat dan meningkatkan makna fungsi kelembagaan sekolah.

Tujuan utama MBS adalah meningkatkan efisiensi, mutu dan pemerataan pendidikan (Mulyasa, 2012). Efisiensi dapat diperoleh dengan adanya keleluasaan mengelolaa sumber daya sekolah, peningkatan partisipasi masyarakat dan birokrasi yang lebih sederhana. Peran orang tua yang terus ditingkatkan diharapkan dapat meningkatkan mutu pendidikan. Peran masyarakat khususnya bagi keluarga mampu dapat meningkatkan pemerataan pendidikan, sehingga masyarakat tidak mampu dapat menjadi tanggungan pemerintah.

\subsection{Tahapan pengelolaan keuangan sekolah}

Otonomi sekolah bukan hanya dibidang akademik, tetapi juga dalam hal pengelolaan keuangan. Sekolah memiliki kewenangan yang luas untuk mengelola sesuai dengan kebutuhan siswa dan capaian yang ingin di peroleh (Vernez,dkk, 2012).

Empat tahapan pengelolaan keuangan sekolah terdiri dari Perencanaan, Pelaksanaan dan Pelaporan seperti pada gambar 2 .

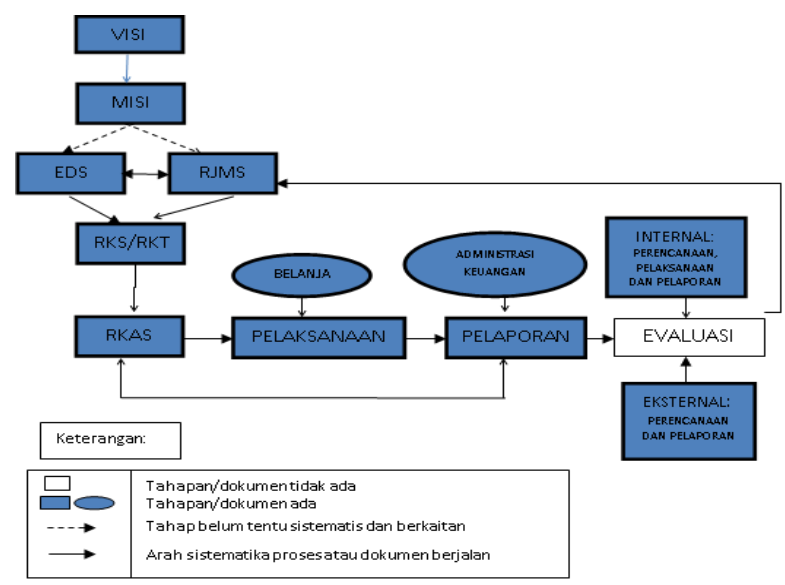

Gambar 2. Tahap Pengelolaan Keuangan Sekolah

Sumber: Rahayu, dkk, 2016

Setiap tahun sekolah harus menyusun rencana kerja dan anggaran sekolah (RKAS). RKAS ini disusun berdasarkan rencana kerja sekolah yang sifatnya tahunan. Dasar penyusunan rencana kerja tahunan sekolah adalah hasil evaluasi diri tahunan sekolah dan rencana jangka menengah sekolah yang harus selaras dengan visi dan misi yang telah ditetapkan. Visi dan misi sekolah juga mengacu kepada visi dan misi Dinas Pendidikan, Visi dan Misi Pemerintah Daerah serta Visi dan Misi Kementerian Pendidikan dan Kebudayaaan.

Penyusunan RKAS yang baik akan menentukan kelancaran dalam pelaksanaan kegiatan, oleh karena itu RKAS harus disusun bersama dibawah koordinasi 
kepala sekolah selaku manajer sekolah. Kepala sekolah harus melibatkan seluruh stakeholders seperti komite sekolah, dewan guru, pegawai, orang tua siswa, tokoh masyarakat dan pihak dinas pendidikan.

Pelaksanaan anggaran sesuai dengan RKAS, sekolah akan melakukan belanja sesuai dengan rencana kegiatan yang telah ditetapkan. RKAS bukan hanya berisi rencana kegiatan yang bersumber dari dana BOS saja, tetapi mencakup seluruh sumber dana yang diperoleh sekolah dalam satu tahun. Dokumen bukti transaksi dari pelaksanaan kegiatan menjadi dokumen sumber untuk melakukan pencatatan yang bermuara kepada laporan sumber dan penggunaan dana sekolah. Pengendalian internal yang baik, seharusnya memisahkan antara bagian pencatatan yang menyusun laporan keuangan sekolah dengan bagian pengelola keuangan atau bendahara sekolah. Sehingga tidak terjadi konflik kepentingan diantara kedua bagian ini.

Laporan sumber dan penggunaan dana sekolah dilaporkan ke berbagai pihak yaitu Dinas Pendidikan dan Kemendikbud serta stakeholders lainnya. Laporan khusus untuk dana BOS setiap triwulan dilaporkan secara on line ke Kemendikbud sesuai dengan tahapan pencairan dana yang diperoleh sekolah. Idealnya laporan sekolah ini dievaluasi baik oleh pihak internal (dibahas bersama kembali seperti membahas RKAS) maupun pihak eksternal dari Manajemen BOS Daerah atau dari inspektorat daerah yang bersangkutan. Hal ini akan meningkatkan akuntabilitas dan transparansi dari pengelolaan keuangan sekolah.

\section{METODOLOGI PENELITIAN}

Objek penelitian ini adalah praktik pengawasan pengelolalaan keuangan sekolah dasar negeri di Kota Jambi. Sekolah dasar di Kota Jambi tersebar pada 6 Unit Pelaksana Teknis Dinas Pendidikan di Tingkat Kecamatan Kota Jambi yaitu UPTD Jambi Timur, UPTD Jambi Selatan, UPTD Pasar, Pelayangan dan Danau Teluk, UPTD Jelutung, UPTD Kotabaru dan UPTD Telanaipura. Penyebaran kuesioner disebarkan sebanyak 60 (10 kuesioner setiap kecamatan). Kuesioner yang dikembalikan dan dapat diolah sebanyak 50\% atau 30 kuesioner.

Jenis data yang digunakan dalam penelitian ini adalah data primer. Data primer dikumpulkan dengan metode wawancara mendalam dan survei dengan kuesioner terkait dengan praktik pengawasan pengelolaan keuangan sekolah. Semua data tersebut diperoleh dari masing-masing sekolah dan pengawas sekolah dasar di Kota Jambi. Wawancara mendalam tidak dilakukan untuk seluruh kecamatan, hanya perwakilan beberapa sekolah saja. Hal ini dilakukan karena tidak semua kepala sekolah bersedia untuk diwawancarai secara mendalam.

Data dianalisis dengan menggunakan metode deskriptif kuantitatif dan kualitatif. Penerapan praktik pengawasan keuangan sekolah diekslporasi dengan menggunakan kuesioner dan wawancara mendalam. Metode kuantitatif digunakan untuk mengolah data kuesioner, sedangkan metode kualitatif digunakan untuk mengolah dana menganalisis data hasil wawancara mendalam.

Denzin dan Lincoln (2009) menyatakan penelitian kualitatif adalah penelitian dengan menggunakan latar alamiah, dengan maksud menafsirkan fenomena yang terjadi dan dilakukan dengan jalan melibatkan berbagai metode yang ada. Moleong, (2005: 5) memaparkan bahwa penelitian kualitatif adalah penelitian yang menggunakan pendekatan naturalistik untuk mencari dan menemukan pengertian atau pemahaman tentang fenomena dalam suatu latar yang berkonteks khusus. Penelitian kualitatif tidak menggunakan prosedur analisis statistik. Penelitian ini berupaya membangun pandangan mereka yang diteliti secara rinci, dibentuk dengan kata-kata sehingga diperoleh gambaran holistik.

Tingkat Praktik pengawasan keuangan sekolah secara umum dianalisis dengan menggunakan bobot dari metode check list. Kuesioner akan dibentuk berdasarkan unsur-unsur pengawasan pengelolaan keuangan sekolah yang seharusnya dilaksanakan oleh sekolah. Pilihan jawaban menggunakan dikotomi "Ya" dan "Tidak". Jawaban "Ya" akan diberikan bobot nilai 1, sedangkan jawaban "Tidak" akan diberikan bobot nilai 0 .

Tingkat penerapan pegawasan pengelolaan keuangan sekolah akan diperoleh dari rumus sebagai berikut:

Tingkat pengawasan $=\underline{n} \times 100 \%$

\section{$\mathrm{k}$}

$\mathrm{n}=$ jumlah unsur pengawasan pengelolaan keuangan sekolah yang dilaksanakan

$\mathrm{k}=$ jumlah seluruh unsur pengawasan pengelolaan keuangan sekolah yang harus dilaksanakan

Hasil jumlah indeks akan menunjukkan bobot penerapan pengawasan keuangan sekolah. Kriteria untuk peringkat bobot ditetapkan sebagai berikut:

\begin{tabular}{|c|l|l|}
\hline No & Jumlah Presentase & Kriteria \\
\hline 1 & Di atas $80-100$ & Sangat Baik \\
\hline 2 & Di atas $70-80$ & Baik \\
\hline 3 & Di atas $60-70$ & Cukup Baik \\
\hline 4 & Di atas $50-60$ & Kurang Baik \\
\hline 5 & Di bawah 50 & Tidak Baik \\
\hline
\end{tabular}

Pengolahan data hasil wawancara menggunakan analisis data kualitatif. Analisis data yang digunakan dalam penelitian ini mengikuti tahap-tahap analisis data penelitian kualitatif model interaktif dari Miles dan Huberman (1992). Tiga tahap analisis data yaitu reduksi data, penyajian data dan penarikan kesimpulan/verifikasi. Model interaktif menunjukkan bahwa ketiga tahap analisis data dilakukan terus menerus dan berulang serta dapat dilakukan bersamaan dengan pengumpulan data. 
Variabel dalam penelitian ini adalah pengawasan pengelolaan keuangan sekolah, yang mengacu kepada pengelolaan keuangan sekolah berdasarkan prinsip MBS yang diatur dalam UU Pengelolaan Pendidikan Dasar. Pengawasan dapat dilihat pada setiap tahapan pengelolaan keuangan sekolah yaitu pengawasan perencanaan dan penganggaran, pengawasan pelaksanaan dan pengawasan pelaporan.

Pengujian keabsahan data pada penelitian ini menggunakan triangulasi data. Teknik pemeriksaan keabsahan data yang memanfaatkan sesuatu yang lain, diluar data itu untuk keperluan pengecekan atau sebagai pembanding terhadap data itu disebut sebagai Triangulasi (Moleong, 2005: 330). Teknik trianggulasi terdiri dari teknik pemeriksaan yang memanfaatkan penggunaan sumber, metode, penyidik dan teori. Triangulasi sumber dan metode untuk menguji keabsahan data digunakan dalam penelitian ini.

\section{HASIL DAN PEMBAHASAN}

\subsection{Pengawasan Perencanaan Keuangan Sekolah}

Otonomi sekolah yang diwacanakan seiring dengan penerapan MBS, bisa jadi masih asing bagi sebagian kepala sekolah. MBS diketahui salah satu model desentralisasi bidang pendidikan, karena lebih efisien dan lebih akuntabel. Reformasi keuangan sekolah di Indoensia terjadi sebagai awal penerapan MBS (Winarti, 2011). Kepala sekolah terbiasa dengan tugas memenuhi tuntutan administratif dan kedinasan (Kartono, 2009, hlm. 17) berkaitan dengan akademik saja selama ini. Kepala sekolah belum terbiasa dengan otonomi pengelolaan keuangan yang diberikan kepada sekolah. Kekuasaan kepala sekolah menjadi tidak terkontrol. Kepala sekolah menikmati ini dengan bergaya komandan (Kartono, 2009, hlm. 19). Kepala sekolah masih memonopoli sekolah, memposisikan dirinya sebagai penguasa sekolah. Semua kebijakan dan kegiatan terpusat pada dirinya (Irawan dkk., 2004, hlm. 113).

Salah satu tahap yang paling penting dalam suatu proses pengelolaan keuangan adalah tahap perencanaan. Peneliti mencoba mengevaluasi proses perencanaan melalui kuesioner dengan mengajukan 8 pertanyaan terkait proses perencanaan keuangan yang dilakukan sekolah. Berdasarkan hasil kuesioner, secara umum pengawasan perencanaan sekolah dasar di Kota Jambi sangat baik, karena mencapai skor 92,86\%. Artinya sudah terdapat pengawasan yang baik dari sisi perencanaan pengelolaan dana di sekolah.

Peneliti juga mengeksplorasi pengawasan perencanaan sekolah ini dengan melakukan wawancara terhadap kepala sekolah, pengawas sekolah dan kepala UPTD. Fenomena menarik ditemukan yaitu perbedaan sekolah melibatkan orang tua siswa dalam proses perencanaan. sekolah telah melibatkan pihak eksternal seperti orang tua, komite dan pengawas sekolah. Beberapa sekolah sudah menerapkan pola partisipatif sangat baik dalam perencanaan keuangan sekolah. Seluruh internal sekolah baik guru dan pegawai berkumpul bersama untuk mendiskusikan rencana kegiatan sekolah sesuai hasil evaluasi diri sekolah. Setelah itu sekolah akan mengadakan rapat lanjutan dengan pihak eksternal.

Rapat diskusi rencana kegiatan dan anggaran sekolah ini berbeda-beda setiap sekolah. Ada sekolah yang mengajak seluruh orang tua dengan sistem bergantian untuk dialog. Sebagian besar sekolah hanya mengajak komite dan perwakilan orang tua siswa dalam proses diskusi. Selain kedua pola tersebut, terdapat juga sekolah yang hanya sekedar mensosialisasikan saja rencana kegiatan sekolah kepada orang tua murid. Biasanya dilakukan pada Minggu awal tahun pelajaran baru.

Keterlibatan pengawas sekolah dalam proses perencanaan ini juga berbeda-beda. Ada sekolah yang ikut melibatkan pengawas dalam perencanaan, namun ada juga sekolah yang belum. Sebaiknya ke depan, pengawas sangat penting terlibat dalam proses perencanaan sekolah. Karena pengawas yang terlibat aktif dalam monitoring dan evaluasi kegiatan akademik sekolah, sehingga dapat memberikan saran untuk memperbaiki kelemahan sekolah. Selain itu, pengawas akan dapat melakukan pengawasan pengelolaan keuangan sekolah, jika sudah dilibatkan secara efektif mulai dari proses perencanaan.

\subsection{Pengawasan Pemanfaatan dan Penatausahaan Keuangan Sekolah}

Pada tahap pelaksanaan anggaran, kepala sekolah harus melakukan pengawasan terhadap penggunaan dana keuangan sekolah. Pengunaan anggaran dana sekolah seharusnya mengacu kepada RKAS yang telah disusun dan disahkan. Perubahan kebutuhan penggunaan dana sekolah yang tidak sesuai dengan RKAS, harus melalui proses revisi anggaran. Alasan yang tepat serta jelas harus diungkap sebagai dasar revisi anggaran. Selain itu, kepala sekolah juga harus memastikan dan mengawasi proses administrasi seperti kelengkapan SPJ dan pembukuan, dilakukan segera setelah terjadinya pengeluaran dana sekolah .

Pengelolaan dana sekolah harus dilakukan secara bertanggungjawab dan transparan (Kemendikbud, 2012). Oleh karena itu, kepala sekolah harus mampu mempertanggungjawabkan penggunaan anggaran dana sekolah secara baik dan benar pada tahap pelaporan. Kewajiban untuk mengkomunikasikan kembali ke seluruh stakeholders sekolah harus dijalankan sebagai wujud transparansi. Transparansi dibutuhkan bukan saja karena keharusan Juknis, tetapi untuk menghindari rasa saling curiga diantara warga sekolah, orang tua, dan pihak lainnya terhadap tim manajemen sekolah dan khususnya terhadap kepala sekolah. Kepercayaan yang telah terjalin akan mengurangi kemungkinan terjadinya konflik sekolah.

Berdasarkan hasil pengolahan kuesioner menunjukkan pengawasan pemanfaatan dan penatausahaan keuangan sekolah dasar di Kota Jambi sudah sangat baik dengan skor $82 \%$. Hal ini berarti 
sudah ada pengawasan yang baik untuk pemanfaatan dana sekolah untuk sekolah dasar di Kota Jambi.

Temuan dari penelitian ini dari proses wawancara dan pengamatan, terdapat dua pola pengelolaan keuangan sekolah yang diteliti yaitu kepala sekolah melibatkan seluruh internal sekolah dan kedua kepala sekolah hanya bergerak dengan tim kecil di sekolah. Hal ini masih sejalan dengan temuan Rahayu, dkk (2015a). Perubahan sistem administrasi telah mengurangi kemungkinan kepala sekolah mampu mengerjakan seluruh tugas penatausahaan sendiri. Pola pengelolaan keuangan yang ideal apabila dilakukan secara gotong royong, dalam arti seluruh stakeholders terlibat dalam pengelolaan keuangan sekolah (Rahayu, dkk, 2015b).

Kepala sekolah memang sebagai penanggung jawab sekaligus manajer dana di sekolah, tetapi bukan berarti semua harus ditangani sendiri. Apabila pekerjaan bisa dibagi bersama, maka ketenangan akan bisa diperoleh. Kepala sekolah yang bekerja sendiri untuk semua urusan yang berkaitan dengan pengelolaan dana untuk kepentingan bersama memang tidak tepat. Akibatnya kepala sekolah sibuk dengan urusan administratif saja, tidak lagi sempat memikirkan hal-hal lain berkaitan dengan pengembangan sekolah. Selain itu, fungsi pengawasan internal atas penggunaan dana sekolah tidak berjalan sama sekali.

Kepala sekolah yang bekerja dengan tim yang dipercaya, sudah mulai membuka diri untuk berbagi peran dengan orang lain. Fungsi manajemen berupa perencanaan, pengkoordinasian, pengarahan dan pengawasan, walaupun masih minimal, sudah mulai bisa terimplementasikan. Kepala sekolah masih berperan cukup kuat pada pola ini, karena yang terlibat masih terbatas, dan orang-orang dekat saja yang dipilih. Fungsi pengawasan menjadi tidak maksimal, karena anggota kelompok cenderung menyetujui saja pemikiran kepala sekolah, agar dianggap mendukung.

Fungsi manajemen secara internal sudah bisa diterapkan pada dengan melibatkan seluruh stakeholder sekolah. Sangat disayangkan, sekolah yang sudah menerapkan cara ini belum berani menyampaikan informasi penggunaan dana secara terbuka. Putusnya informasi setelah proses penyusunan anggaran bagi pihak luar sekolah tersebut, menyebabkan evaluasi dan pengawasan dana sekolah oleh orang tua dan masyarakat menjadi terbatas. Keputusan kepala sekolah untuk tidak terbuka lebih banyak karena rasa takut dan kekhawatiran pribadi yang seharusnya tidak perlu. Kebijakan-kebijakan yang terpaksa harus diambil oleh kepala sekolah, selama itu benar dan tidak untuk menguntungkan diri sendiri atau kelompok tertentu, tidaklah salah. Karena hal-hal semacam itu, terkadang terpaksa dilakukan demi tetap berlangsungnya proses pendidikan di sekolah. Seharusnya, kepala sekolah harus lebih meningkatkan kepercayaan diri untuk menyampaikan kebijakan-kebijakan sekolah agar dapat menggerakkan orang lain.

\subsection{Pengawasan Pelaporan Keuangan Sekolah}

Proses pelaporan merupakan bentuk pertanggungjawaban penggunaan dana di sekolah. Dana yang diterima oleh hampir seluruh sekolah adalah BOS yang bersumber dari APBN. Oleh karena itu, pembahasan sistem pelaporan pada riset ini akan lebih banyak fokus ke dana ini.

Pelaporan dana bantuan pemerintah, dana DAK dan dana lainnya sifatnya lebih sering tahunan. Dana BOS agak berbeda. Pelaporan dana BOS ini harus dibuat per triwulan dan tahunan. Laporan ini harus ditandatangani oleh bendahara BOS, kepala sekolah dan komite sekolah dalam bentuk format K7-a. Lampiran dari laporan ini adalah pernyataan pertanggungjawaban kepala sekolah atas penggunaan dana BOS untuk keperluan operasional sekolah. Kepala sekolah juga menyatakan kesediaan untuk dikenakan sanksi dan tuntutan ganti rugi atau tuntutan lain apabila terdapat ketidaksesuaian kemudian hari.

Sejak tahun 2013, sekolah harus melaporkan secara on line laporan penggunaan dana BOS ini melalui website www.bos.kemdikbud.go.id. Laporan triwulanan juga harus disampaikan ke SKPD pendidikan Kabupaten/Kota. Seluruh laporan triwulan dan tahunan berserta dokumennya, disimpan oleh sekolah untuk keperluan monitoring dan audit. Kepala sekolah selaku manajer BOS sekolah harus menyampaikan laporan pertanggungjawaban kepada stakeholders sekolah. Laporan BOS 03 (rencana penggunaan dana BOS periode tertentu) dan BOS 04 (laporan penggunaan dana BOS periode tertentu) diumumkan di papan pengumuman sekolah (Kemendikbud, 2012).

Sebenarnya form-form pelaporan dana BOS dapat juga dimanfaatkan sekaligus untuk melaporkan danadana sekolah yang lain untuk kepentingan kepada orang tua dan komite sekolah. Sebagian besar sekolah hanya melaporkan dana BOS saja, karena berpandangan untuk dana DAK dan bantuan pemerintah mempunyai alur pelaporan tersendiri. Sedangkan untuk dana bersumber dari pendapatan asli sekolah seringkali belum terlaporkan ke pihak eksternal sekolah.

Tingkat pengawasan pelaporan keuangan sekolah dasar di Kota Jambi tergolong baik karena berada pada skor 76,34 (Kategori baik). Namun di lapangan masih sangat sering ditemukan keterlambatan dalam pelaporan dana sekolah. Pihak yang sangat mungkin untuk diminta melakukan pengawasan bagi sekolah adalah pengawas sekolah. Sangat disayangkan pengawas sekolah hanya fokus kepada laporan-laporan yang sifatnya akademik saja.

Pengawas sekolah diharapkan dapat melakukan pengawasan untuk seluruh aspek di sekolah. Hal ini akan mendukung penerapan MBS di sekolah. Penerapan MBS yang optimal akan mempengaruhi kinerja dan kepuasan kerja serta meningkatkan motivasi pegawai (Hutabarat, 2015). 
Ke depan, pengawas sekolah juga perlu dibekali dengan pengetahuan tentang pengelolaan keuangan sekolah, sehingga bisa efektif dalam melakukan fungsi pengawasan. Peningkatan pemahaman dapat dilakukan melalui kegiatan pelatihan, bimbingan teknis dan sosialisasi.

\section{SIMPULAN DAN SARAN}

\subsection{Simpulan}

Berdasarkan hasil penelitian maka diperoleh beberapa simpulan sebagai berikut:

1. Beberapa jenis dana yang menjadi sumber keuangan sekolah yaitu dana bantuan pemerintah (Dana bantuan pemerintah), Dana Alokasi Khusus, Dana BOS yang bersumber dari APBN (pusat) dan Dana BOS dari APBD (daerah) serta pendapatan asli sekolah. Jenis Dana yang belum banyak dipahami oleh sekolah adalah pendapatan asli sekolah. Seluruh sekolah telah mendapat alokasi dana BOS yang bersumber dari APBN. Namun tidak seluruh sekolah mendapat dana bantuan pemerintah (Bantah) dan DAK. Dana BOS APBD dialokasikan dalam bentuk honor bagi guru dan pegawai non PNS.

3. Pengawasan keuangan sekolah dasar di Kota Jambi pada tahap perencanaan sudah baik. Sekolah sudah melibatkan orang tua dan komite dalam proses penyusunan anggaran sekolah, walaupun masih terdapat sekolah yang sifatnya hanya melakukan sosialisasi saja.

4. Pengawasan keuangan sekolah dasar di Kota Jambi pada tahap pemanfaatan dan penatausahaan sudah baik.

5. Pengawasan keuangan sekolah dasar di Kota Jambi pada tahap pelaporan juga sudah baik.

\subsection{Saran}

Beberapa saran yang diberikan oleh tim peneliti berdasarkan hasil penelitian ini adalah sebagai berikut:

1. Sosialisasi pengelolaan dana sekolah bukan hanya diberikan bagi kepala sekolah dan bendahara saja, tetapi juga diperlukan bagi orang tua, guru dan komite sekolah. Sehingga stakeholders sekolah dapat mengetahui dan memahami proses pengelolaan keuangan sekolah.

2. Dinas Pendidikan Kota Jambi perlu melakukan pelatihan dan bimbingan teknis bagi pengawas sekolah tentang pengelolaan keuangan sekolah. Hal ini dapat meningkatkan fungsi pengawasan yang diberikan oleh pengawas sekolah sampai ke aspek keuangan.

3. Pemerintah Kota Jambi sebaiknya terus meningkatkan alokasi anggaran untuk membantu operasional sekolah, khususnya bagi sekolah dengan jumlah siswa yang sedikit.

\section{DAFTAR REFERENSI}

Bastian, Indra. 2007. Akuntansi Pendidikan. Jakarta: Erlangga.

BPS, 2018, Indeks Pembangunan Manusia, https://www.bps.go.id/pressrelease/2018/04/16/1 535/indeks-pembangunan-manusia--ipm-indonesia-pada-tahun-2017-mencapai-70-81-kualitas-kesehatan--pendidikan--danpemenuhan-kebutuhan-hidup-masyarakatindonesia-mengalami-peningkatan.html

Denzin, N. K., dan Lincoln, Y. S. 2009. Pendahuluan: Memasuki Bidang Penelitian Kualitatif (Dariyatno, B. S. Fata, Abi dan J. Rinaldi, Trans.). In N. K. Denzin dan Y. S. Lincoln (Eds.), Handbook of Qualitiative Research. Yogyakarta: Pustaka Pelajar.

Fattah, N. 2012. Analisis Kebijakan Pendidikan. Bandung: PT Rosda Karya.

Hutabarat, Wesly, 2015, Implementation of School Based Management in Indonesia (Affecting Work Motivation, Job Satisfaction and Teacher Job Performance), International Journal of Sciences Basic and Applied Research (IJSBAR), Vol. 22, No. 2, PP 428-440

Irawan, A., Eriyanto, Djani, L., dan Sunaryanto, A. 2004. Mendagangkan Sekolah: Studi Kebijakan Manajemen Berbasis Sekolah di DKI Jakarta. Jakarta: Indonesia Corruption Watch.

Kartono, S. 2009. Sekolah Bukan Pasar: Catatan Otokritik Seorang Guru. Jakarta: Kompas.

Kemdikbud, dan Kemenag. 2012. Materi Pelatihan Sekolah/Madrasah: Peningkatan Manajemen Melalui Penguatan Tata Kelola dan Akuntabilitas di Sekolah/Madrasah. Jakarta: Dirjen Pendidikan Dasar

Kemendikbud,2018, Alokasi Anggaran Dana BOS Per Triwulan,https://bos.kemdikbud.go.id/index.php /report_rkun_rkud?filter_tahun=2018\&filter_tri wulan=1\&submit=filter_report

Miles, M. B., dan Huberman, A. M. 1992. Analisis Data Kualitatif (T. R. Rohidi, Trans.). Jakarta: UI Press.

Minarti, S. 2011. Manajemen Sekolah: Mengelola Lembaga Pendidikan Secara Mandiri. Jogyakarta: Ar Ruzz Media.

Moleong, L. J. 2005. Metodologi Penelitian Kualitatif. Remaja Rosdakarya: Bandung.

Mulyasa. 2012. Manajemen Berbasis Sekolah: Konsep, Strategi dan Implementasi. Bandung: PT Remaja Rosdakarya.

Rahayu, Sri, Unti Ludigdo, Gugus irianto, \& Nurkholis. 2015a. Three Budgeting Pattern of School 
Operational Assistance Fund. Australian Journal of Basic and Applied Sciences, 9(27) August 2015, Pages: 553-559

Rahayu, Sri, Unti Ludigdo, Gugus irianto, \& Nurkholis. 2015b. Budgeting Of School Operational Assistance Fund Based Of Gotong Royong. 2nd Global Conference on Business and Social Science, Bali, 17-18 September 2015

Rahayu, Sri, 2016. Institutionalization Process of SOA Funds Budgeting at Basic Education Institutions in Indonesia. Research Journal of Finance and Accounting. ISSN 2222-1697 (Paper) ISSN 2222-2847 (Online) Vol.7, No.4, 2016

Rifai, M. 2011. Politik Pendidikan di Indonesia. Jogyakarta: Ar Ruzz Media.

UNDP. 2013. Human Development Index : 15 November, 2013. http://hdr.undp.org/en.

UNDP, 2018, Human Development Indices and Indicators: 2018 Statistical Update, Briefing note for countries on the 2018 Statistical Update Indonesia.

http://hdr.undp.org/sites/all/themes/hdr_theme/c ountry-notes/IDN.pdf. di akses tanggal 5 September 2018

Vernez, G. Karam R \& Marshall J.H. (2012), Implementation of School Based Management in Indonesia, Santa Monica, RAND Corporation.

Winarti, E, 2011, School Based Management: The Challenges of Its Implementation in Indonesia, Orientasi Baru, Vol. 20, No. 1, April

Zazin, N. 2011. Gerakan Menata Mutu Pendidikan:

Teori dan Aplikasi. Jogyakarta: Ar Ruzz Media 